\title{
ANALISIS ARUS KAS, DISAGREGAT LABA DALAM MEMPREDIKSI ARUS KAS MASA DEPAN
}

\author{
Synthia Madyakusumawati \\ Atma Jaya Catholic University \\ synthia.madya@atmajaya.ac.id
}

\begin{abstract}
The purpose of this research is to analyze the impact of cash flow, earnings and disagregat earnings in predicting future cash flow. Hypothesis testing is carried out by using regression model using financial statement data from BEI 2012-2016. The result of this study indicate that the current cash flow have the most powerful tools in predicting future cash flow
\end{abstract}

Keyword : cash flow, aggreagate earnings, earnings, future cash flow

\begin{abstract}
ABSTRAK: Tujuan dari penelitian ini adalah untuk menganalisis dampak arus kas, pendapatan dan disagregat laba dalam memprediksi arus kas masa depan. Pengujian hipotesis dilakukan dengan menggunakan model regresi dengan menggunakan data laporan keuangan dari BEI 20122016. Hasil penelitian ini menunjukkan bahwa arus kas saat ini memiliki alat yang paling kuat dalam memprediksi arus kas masa depan
\end{abstract}

Kata kunci: arus kas, pendapatan agregat, pendapatan, arus kas masa depan

\section{PENDAHULUAN}

Laporan keuangan merupakan salah satu bentuk pertanggungjawaban manajemen perusahaan terhadap para investornya. Hal tersebut juga dikemukakan dalam PSAK No.1 (2015) bahwa tujuan laporan keuangan adalah untuk memberikan informasi terkait posisi keuangan, kinerja keuangan, dan arus kas entitas yang bermanfaat bagi sebagian besar pengguna laporan keuangan dalam pembuatan keputusan ekonomi. SFAC (Statement of Financial Accounting Concept) No.8 Ob. 3 Tahun 2010 bahwa: "Keputusan oleh investor yang ada dan potensial tentang membeli, menjual, atau memegang instrumen ekuitas dan hutang tergantung pada tingkat pengembalian yang mereka harapkan dari investasi di instrumen tersebut, misalnya pembayaran dividen, pokok dan bunga, atau kenaikan harga pasar. Investor, pemberi pinjaman, dan kreditur lainnya berekspektasi mengenai pengembalian berdasarkan pada penilaian mereka atas waktu, jumlah, dan ketidakpastian (prospek) mendatang arus kas bersih entitas". Informasi mengenai arus kas bersih ini diperoleh dari salah satu laporan keuangan yaitu laporan arus kas. Laporan arus kas melaporkan jumlah arus kas masuk serta jumlah arus kas keluar perusahaan dalam periode tertentu. Informasi yang terkandung dalam arus kas adalah kemampuan perusahaan dalam menghasilkan kas dari aktivitas perusahaan. Aktivitas perusahaan yang disajikan dalam 3 bagian arus kas yaitu arus kas aktivitas operasi, arus kas aktivitas investasi dan arus kas aktivitas pendanaan (Reeve Warren 2016). Laporan arus kas adalah salah satu alat analisis yang digunakan dalam memprediksi arus kas di masa yang akan datang. Proyeksi arus kas masa depan ini menjadi salah satu sumber informasi bagi investor atau para pengguna laporan lainnya dalam pengambilan keputusan ekonomi. Hassan Karimi (2013) menyatakan bahwa arus kas kegiatan operasi mempengaruhi prediksi arus kas kegiatan operasi di masa depan. Hal ini juga didukung oleh penelitian Aghaei \& Shakeri (2010), yang meneliti mengenai kemampuan arus kas dan komponen laba berhubungan dengan ramalan arus kas. Hasil penelitian tersebut menunjukan bahwa laba, arus kas, dan komponen akrual memiliki kemampuan untuk 
memprediksi arus kas masa depan tetapi, arus kas memiliki kemampuan prediksi yang lebih baik dari pada laba. Laporan laba rugi melaporkan kinerja dari suatu perusahaan selama periode tertentu yang dibutuhkan untuk mengambil keputusan tentang sumber ekonomi yang akan dikelola oleh suatu perusahaan. Munawir (2010, p. 26) mengatakan, bahwa laporan laba rugi merupakan suatu laporan yang sistematis tentang penghasilan, beban, laba-rugi yang diperoleh oleh suatu perusahaan selama periode tertentu. Laporan laba rugi disajikan dengan metode akrual basis. Menurut Subramanyam et al. (2010), laba akrual lebih unggul dalam memprediksi arus kas masa depan.

\section{TINJAUAN LITERATUR}

Laporan keuangan merupakan bentuk pelaporan yang terstruktur dari posisi keuangan dan kinerja keuangan sebuah perusahaan. Menurut PSAK No.1 Tahun 2015, Tujuan laporan keuangan adalah untuk memberikan informasi mengenai posisi keuangan, kinerja keuangan, dan arus kas perusahaan yang bermanfaat bagi sebagian besar pengguna laporan keuangan dalam pembuatan keputusan ekonomi. Laporan keuangan juga menunjukan pertanggungjawaban manajemen atas penggunaan sumber daya yang dipercayakan kepada mereka. Salah satu bagian dari laporan keuangan yang menjadi pusat perhatian adalah laporan laba rugi, laporan ini menyajikan informasi keuntungan atau kerugian dari sebuah perusahaan.

Laba merupakan selisih positif dari penghasilan dan beban dalam suatu periode tertentu. Menurut Stice \& Skousen (2007) laba adalah jumlah residual yang tertinggal setelah semua beban dikurangkan pada penghasilan. Unsur yang secara langsung berkaitan dengan pengukuran laba adalah penghasilan dan beban. Penghasilan (income) merupakan kenaikan manfaat ekonomi selama suatu periode akuntansi dalam bentuk pemasukan atau penambahan aktiva atau penurunan kewajiban yang menyebabkan kenaikan ekuitas yang tidak berasal dari kontribusi penanaman modal. Penghasilan dapat diklasifikasikan menjadi pendapatan (revenue) yang merupakan penghasilan yang timbul dari aktivitas operasi perusahaan, dan keuntungan (gain) yang merupakan penghasilan dari aktivitas yang rutin, seperti pengalihan aktiva lancar, dan kenaikan jumlah aktiva jangka panjang. Sedangkan unsur kedua dari laba adalah beban yang merupakan penurunan manfaat ekonomi selama suatu periode akuntansi dalam bentuk arus kas keluar atau berkurangnya aktiva atau terjadinya kewajiban yang menyebabkan penurunan ekuitas yang tidak menyangkut pembagian kepada penanam modal. Beban sendiri diklasifikasikan menjadi expense yang merupakan pengeluaran dari aktivitas operasi perusahaan, dan rugi (loss) yang merupakan pengeluaran dari aktivitas perusahaan yang jarang terjadi, seperti bencana, dan pelepasan aktiva tidak lancar. Selisih bersih antara penghasilan dan beban sering digunakan sebagai ukuran kinerja perusahaan, pengukuran efisiensi manajemen, sebagai pengukuran keberhasilan serta pedoman dalam mengambil keputusan manajerial di masa yang akan datang dan bagi para investor informasi mengenai laba digunakan untuk menilai imbalan investasi (return of investment) dan penghasilan per saham (earning per share) di masa yang akan datang. Informasi mengenai laba dapat dilihat dalam Laporan laba rugi dan penghasilan komprehensif lain. Laporan tersebut dapat digunakan oleh para pengguna laporan sebagai acuan dalam pengambilan keputusan ekonomi. Laporan laba rugi adalah laporan utama yang menginformasikan mengenai kinerja dan profitabilitas perusahaan. Informasi tersebut seringkali digunakan untuk memperkirakan kemampuan suatu perusahaan dalam menghasilkan kas dan setara kas di masa yang akan datang. Ebaid (2011) dalam penelitiannya yang menyatakan bahwa laba bersih mempunyai kemampuan prediktif yang unggul dalam memprediksi arus kas masa 
depan dibandingkan dengan arus kas historis. Maka hipotesis pertama dari penelitian ini adalah

H1 : Laba bersih Tahun Ini Menggungguli Arus Kas dalam Memprediksi Arus Kas Masa Depan

Laporan arus kas melaporkan arus kas masuk dan arus kas keluar suatu perusahaan selama periode tertentu sehingga pengguna laporan dapat mengetahui aliran kas yang diperoleh dan digunakan seacara tunai. Dalam PSAK No. 2 Tahun 2015, Laporan arus kas mempunyai manfaat untuk menyediakan informasi yang memungkinkan para pengguna untuk mengevaluasi perubahan dalam asset netto perusahaan, struktur keuangannya, dan kemampuannya untuk mempengaruhi jumlah serta waktu arus kas dalam rangka penyesuaian terhadap keadaan dan peluang yang berubah. Adapun tujuan laporan arus kas yang sejalan dengan manfaat laporan arus kas, menurut PSAK No.2 Tahun 2015 adalah untuk menilai kemampuan entitas dalam menghasilkan kas dan setara kas serta menilai kebutuhan entitas untuk menggunakan arus kas tersebut, dan laporan arus kas ditujukan untuk memberikan informasi yang relevan kepada para pengguna dalam proses pengambilan keputusan ekonomi. Laporan arus kas terdiri dari tiga aktivitas, yaitu aktivitas operasional, aktivitas pendanaan, dan aktivitas investasi. Klasifikasi menurut aktivitas memberikan informasi kepada para pengguna untuk mengevaluasi pengaruh aktivitas tersebut terhadap posisi keuangan perusahaan juga terhadap jumlah kas dan setara kas. Menurut Kieso, et al (2008, p. 213) aktivitas dalam laporan arus kas adalah sebagai berikut : 1. Aktivitas operasi meliputi pengaruh kas dari transaksi yang digunakan untuk menentukan laba bersih. 2. Aktivitas pendanaan merupakan aktivitas yang meliputi perolehan sumber daya dari pemilik dan komposisinya kepada mereka dengan pengembalian atas dan dari investasinya juga meliputi peminjaman uang dari kreditor serta pelunasannya. 3. Aktivitas investasi meliputi pemberian dan penagihan pinjaman serta perolehan dan pelepasan investasi (baik utang maupun ekuitas) serta properti, pabrik, dan peralatan.

Laba bersih didapatkan dari penghasilan utama perusahaan setelah dikurangi dengan bebanbeban yang terjadi. Penghasilan dan beban tersebut dapat berupa penerimaan atau pembayaran kas secara tunai dan penerimaan atau pembayaran kas secara kredit. Berkaitan dengan pencatatan penghasilan dan beban terdapat dua metode yang digunakan, yaitu metode cash basis dan metode accrual basis. Metode cash basis merupakan metode pencatatan dimana, pendapatan dan beban diakui ketika kas diterima dan dikeluarkan oleh perusahaan. Sedangkan metode accrual basis merupakan metode pencatatan dimana, pendapatan dan beban diakui ketika transaksi terjadi dan direalisasikan meskipun tanpa adanya arus kas masuk dan arus kas keluar. Laporan keuangan termasuk laporan laba rugi dan komprehensif lainnya disusun menggunakan basis akrual kecuali laporan arus kas. Meskipun penyusunan laporan laba rugi menggunakan basis akrual tetapi ada unsur basis kas yang terdapat dalam laba bersih, seperti penerimaan dan pembayaran kas secara tunai (real time) yang berkaitan dengan aktivitas operasi perusahaan. Maka dapat disimpulkan bahwa Laba bersih = Arus kas operasi + akrual. Laba yang dibagi menjadi arus kas operasi dan komponen akrual inilah yang disebut dengan laba disagregat. Komponen akrual dalam laba secara siginifkan meningkatkan kemampuan prediktif laba untuk menilai arus kas di masa yang akan datang hal ini juga dinyatakan dalam, SFAC No.8 Ob. 17 bahwa: "Akuntansi akrual menggambarkan efek dari transaksi, dan peristiwa lain dan keadaan pada 
sumber-sumber ekonomi suatu entitas pelaporan dan klaim pada periode dimana efek tersebut terjadi, bahkan jika penerimaan kas yang dihasilkan dan pembayaran terjadi dalam periode yang berbeda. Hal ini penting karena informasi tentang sumber-sumber ekonomi suatu entitas pelaporan dan klaim dan perubahan dalam sumber daya ekonomi dan klaim selama periode itu memberikan dasar yang lebih baik untuk menilai kinerja entitas lalu dan masa depan daripada hanya informasi tentang penerimaan dan pengeluaran kas selama periode itu". Informasi dari metode pencatatan akrual dinilai lebih tepat waktu, karena arus kas tidak selalu terjadi bersamaan dengan aktivitas usaha. Komponen akrual juga sesuai dengan prinsip matching dimana beban diakui bersamaan dengan pendapatan dalam suatu periode, walaupun adanya perpindahan kas. Menurut Subramanyam dan Wild (2010), menyatakan bahwa laporan laba rugi berbasis akrual lebih relevan dalam mengukur kapasitas dan kinerja perusahaan untuk menghasilkan kas saat ini dan pada masa mendatang. Keunggulan akrual dalam menyajikan informasi relevan atas kinerja dan kondisi keuangan suatu perusahaan, dan untuk memprediksi arus kas masa depan adalah:

a. Pencatatan dan pengakuan laba dengan basis akrual lebih unggul untul menilai kinerja keuangan dibandingkan dengan arus kas.

b. Kondisi keuangan pencatatan secara akrual menghasilkan kondisi neraca yang lebih akurat dalam merefleksikan sumber daya yang tersedia bagi suatu perusahaan untuk menghasilkan arus kas masa depan

c. Prediksi arus kas masa depan laba yang berbasis akrual dinilai unggul dalam memprediksi arus kas masa depan.

Komponen akrual ini dipercaya menjadi salah satu faktor yang menguatkan laba bersih dalam memprediksi arus kas masa depan. Hal ini juga ditunjukan dari penelitian oleh Ebaid (2011), yang menyimpulkan bahwa laba yang didisagregatkan dan komponen akrual merupakan komponen utama yang meningkatkan kemampuan prediksi laba untuk memprediksi arus kas masa yang akan datang. Maka hipotesis kedua dari penelitian ini yaitu

H2 : Komponen Laba Disagregat Mengungguli Kemampuan Laba dalam Memprediksi Arus Kas Masa Depan

\section{METODE PENELITIAN}

\section{1 Model Penelitian}

\section{Model 1}

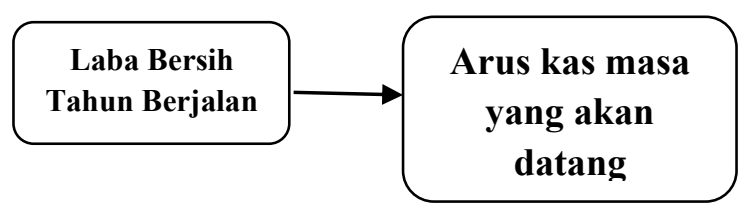

Model 2

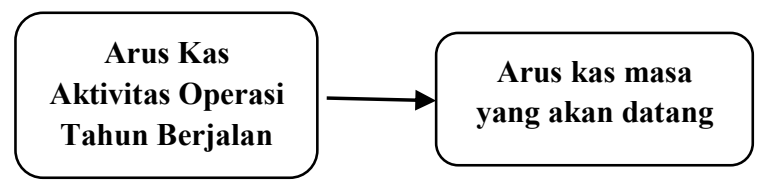

\section{Model 3}

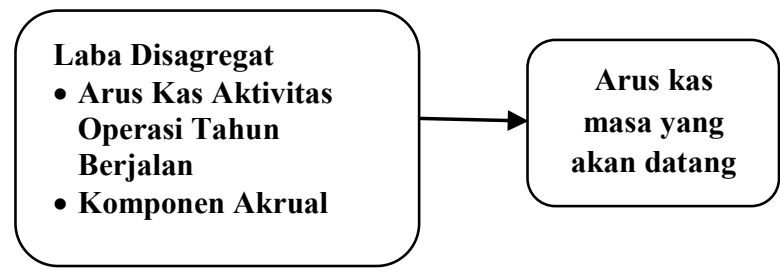

\section{2 Definisi Operasional Variabel}

Variable dependen dalam penelitian ini merupakan arus kas masa depan 
sedangkan variabel independen terdiri dari laba, arus kas, dan komponen laba ( komponen akrual dan arus kas operasi).

\section{Variabel dependen}

\section{Arus Kas operasi tahun $t+1$}

Variabel dependen dari penelitian ini adalah arus kas masa depan, yang merupakan penerimaan dan pengeluaran kas perusahaan pada masa depan. Laporan arus kas melaporkan informasi mengenai arus kas masuk dan arus kas keluar dari tiga aktivitas yaitu, aktivitas operasi, investasi, dan pendanaan. Dalam penelitian ini variabel dependen diukur dari total arus kas aktivitas operasi yang terdapat di laporan keuangan perusahaan berupa laporan arus kas aktivitas operasi dari tahun 2012 sampai dengan tahun 2016. Data yang diukur adalah data laporan arus kas aktivitas operasi di tahun selanjutnya yaitu $\mathrm{CFO}_{\mathrm{t}+1}$. Arus kas aktivitas operasi melaporkan arus kas keluar dan arus kas masuk dalam aktivitas utama perusahaan yang menentukan kinerja serta kemampuan perusahaan dalam memelihara likuiditasnya.

Variabel independen

Variabel independen dari model 1

$:$ CFO $_{t+1}=\alpha_{0}+\alpha_{1}$ EARN $_{t}+\mu_{t}$

EARNt (Laba tahun t)

Laba yang digunakan dalam penelitian ini adalah laba bersih setelah disesuaikan dengan pajak. Hasil tersebut diperoleh dari angka yang menunjukan selisih antara seluruh penjualan dikurangi bebanbeban, pajak penghasilan dari kegiatan operasi perusahaan dan non operasi perusahaan, serta pos-pos luar biasa lainnya pada periode tertentu

Variabel independen dari model 2

: $\mathrm{CFO}_{\mathrm{t}+1}=\alpha_{0}+\alpha_{1} \mathrm{CFO}_{\mathrm{t}}+\mu_{\mathrm{t}}$
Arus kas aktivitas operasi tahun t

Dalam penelitian ini arus kas aktivitas operasi yang digunakan adalah arus kas bersih, dimana merupakan selisih antara arus kas masuk dan arus kas keluar. Arus kas bersih dari aktivitas operasi diperoleh dari laporan keuangan tahunan yaitu arus kas bersih aktivitas operasi tanggal 31 Desember.

Variabel independen dari model 3 : $\mathrm{CFO}_{\mathrm{t}+1}=\alpha_{0}+\alpha_{1} \mathrm{CFO}_{\mathrm{t}}+\alpha_{2} \mathrm{ACC}_{\mathrm{t}}+\mu_{\mathrm{t}}$

\section{Laba disagregat}

Laba disagregat adalah laba yang terbagi atas dua komponen utama yaitu, arus kas operasi dan komponen akrual. Arus kas operasi yang digunakan adalah arus kas bersih dari aktivitas operasi pada laporan arus kas perusahaan, sedangkan komponen akrual didapatkan dari pengurangan laba bersih setelah pajak yang ada dalam laporan laba rugi komprehensif dengan arus kas bersih aktivitas operasi yang terdapat pada laporan arus kas.

\section{3 Metode Pengumpulan Data}

Penelitian ini menggunakan data sekunder yang diambil dari laporan keuangan perusahaan manufaktur yang terdaftar di Bursa Efek Indonesia (BEI). Penelitian ini juga menggunakan laporan keuangan perusahaan manufaktur selama lima tahun, yaitu tahun 2012-2016. Data sekunder dalam penelitian ini bersifat kuantitatif yaitu laporan keuangan tahunan perusahaan.

\section{4 Metode Analisis Data}

Statistika deskriptif digunakan untuk mendeskripsikan variabel-variabel dalam penelitian ini.

\section{Pengujian asumsi Klasik}

Pengujian ini terdiri dari Uji Normalitas, Multikolinearitas, Heteroskedastisitas, Autokorelasi

\section{Analisis Regresi Berganda}


Model prediksi yang digunakan dalam penelitian ini terdiri dari tiga persamaan, yaitu sebagai berikut:

Persamaan (1) digunakan untuk menguji pengaruh laba agregat terhadap arus kas operasi dalam satu tahun mendatang.

$\mathrm{CFO}_{\mathrm{t}+1}=\alpha_{0}+\alpha_{1}$ EARN $_{\mathrm{t}}+\mu_{\mathrm{t}}$

Persamaan (2) digunakan untuk menguji pengaruh arus kas operasi terhadap arus kas operasi dalam satu tahun yang akan datang. $\mathrm{CFO}_{\mathrm{t}+1}=\boldsymbol{\alpha}_{0}+\boldsymbol{\alpha}_{1} \mathrm{CFO}_{\mathrm{t}}+\boldsymbol{\mu}_{\mathrm{t}}$

Persamaan (3) digunakan untuk menguji pengaruh laba disagregat yang terdiri dari arus kas operasi dan total komponen akrual terhadap arus kas operasi satu tahun mendatang

$\mathrm{CFO}_{\mathrm{t}+1}=\alpha_{0}+\alpha_{1} \mathrm{CFO}_{\mathrm{t}}+\alpha_{2} \mathrm{ACC}_{\mathrm{t}}+\mu_{\mathrm{t}}$

\section{Keterangan :}

$\mathbf{C F O}_{\mathbf{t + 1}}$ : Arus kas operasi pada periode selanjutnya

$\begin{array}{ll}\boldsymbol{\alpha}_{\mathbf{0}}, \boldsymbol{\alpha}_{\mathbf{1}}, \boldsymbol{\alpha}_{\mathbf{2}} & : \text { Koefisien } \\ \mathrm{t} & : \text { Tahun amatan }\end{array}$

EARN $_{\mathbf{t}}$ : Laba bersih pada periode $t$

CFO $_{\text {t }} \quad$ : Arus kas operasi pada periode $\mathrm{t}$
$\mathrm{ACC}_{\mathbf{t}}$ : Total komponen akrual
$=\mathrm{EARN}_{\mathrm{t}}-\mathrm{CFO}_{\mathrm{t}}$
$\boldsymbol{\mu} \quad$ : Error term

Hipotesis pertama dibuktikan melalui angka Adj $\mathrm{R}^{2}$ dan tingkat signigikansi dari uji t variabel dari model pertama dan kedua, angka Adj $\mathrm{R}^{2}$ yang lebih tinggi menunjukkan bawah model tersebut lebih unggul dalam memprediksi arus kas di masa depan.

Hipotesis kedua dibuktikan melalui laba yang didisagregatkan dan komponen akrual merupakan komponen utama yang meningkatkan kemampuan prediksi laba untuk memprediksi arus kas masa yang akan datang. Jika angka $\mathrm{Adj} \mathrm{R}^{2}$ dan tingkat signigikansi dari uji $\mathrm{t}$ variabel pada model ke tiga paling tinggi, maka terbukti laba yang didisagregatkan akan meningkatkan kemampuan prediksi laba untuk memprediksi arus kas masa yang akan datang.

\section{Analisa dan Pembahasan}

Penelitian ini menganalisis apakah laba dapat memprediksi arus kas di masa mendatang dengan lebih tepat dibandingkan arus kas masa kini, dan apakah laba disagregat akan meningkatkan kemampuan prediksi laba untuk memprediksi arus kas masa yang akan datang. Penelitian ini menggunakan data perusahaan publik yang terdaftar di Bursa Efek Indonesia. Jumlah sampel yang digunakan adalah 248 tahun perusahaan (manufaktur dan jasa) yang telah go public di BEI selama periode $2012-2016$

\subsection{Gambaran Umum Data}

Tabel 4.1

Statistik Deskriptif

\begin{tabular}{|l|l|l|}
\hline \multicolumn{3}{|c|}{ EARN(t)LABA BERSIH } \\
\hline Maximum & 23.317 .000 .000 .000 & TLKM 2015 \\
\hline Mean & 1.500 .721 .026 .249 & \\
\hline Minimum & 1.933 .819 .152 & INDS 2015 \\
\hline
\end{tabular}

\begin{tabular}{|l|r|c|}
\hline \multicolumn{3}{|c|}{ ACC (t) L.bersih-cfo } \\
\hline Maximum & 13.812 .000 .000 .000 & ASII 2012 \\
\hline Mean & $(192.428 .034 .460)$ & \\
\hline Minimum & $(20.352 .000 .000 .000)$ & TLKM 2015 \\
\hline
\end{tabular}

Laba bersih tertinggi diperoleh oleh PT Telkom pada tahun 2015, sedangkan yang paling kecil dimiliki oleh PT Indospring pada tahun 2015.

Arus Kas Operasi terbesar dimiliki oleh PT Telkom tahun 2016, sedangkan yang paling minimum adalah PT Trisula tahun 2014. Akrual yang dihitung dari laba disgregatkan, paling tinggi diperoleh Astra International tahun 2015, sedangakan akrual yang paling minimum diperoleh PT Telkom Tahun 2015 
Dari Model 2 : $\mathrm{CFO}_{\mathrm{t}+1}=\boldsymbol{\alpha}_{0}+\boldsymbol{\alpha}_{1} \mathrm{CFO}_{\mathrm{t}}+$ $\mu_{\mathrm{t}}$

\subsection{Uji Asumsi Klasik}

Dalam analisis regresi berganda, dilakukan beberapa pengujian, yaitu normalitas, multikolinearitas, heteroskedastisitas, dan autokorelasi. Hasil dari masing-masing pengujian tersebut yaitu sebagai berikut:

\subsubsection{Uji Normalitas}

Uji normalitas dilakukan untuk menguji dalam model regresi berganda berasal dari populasi yang terdistribusi normal. Pengujian normalitas dilakukan dengan menggunakan analisis grafik. Dalam analisis grafik digunakan metode normal probability plot, distribusi normal akan ditunjukkan dengan terbentuknya satu garis lurus diagonal

Gambar 4.1

Hasil Pengujian Normalitas Laba Agregat

Dari model $1:$ CFO $_{t+1}=\alpha_{0}+\alpha_{1}$ EARN $_{t}$ $+\mu_{\mathrm{t}}$

\section{Normal P-P Plot of Regression Standardized Residual}

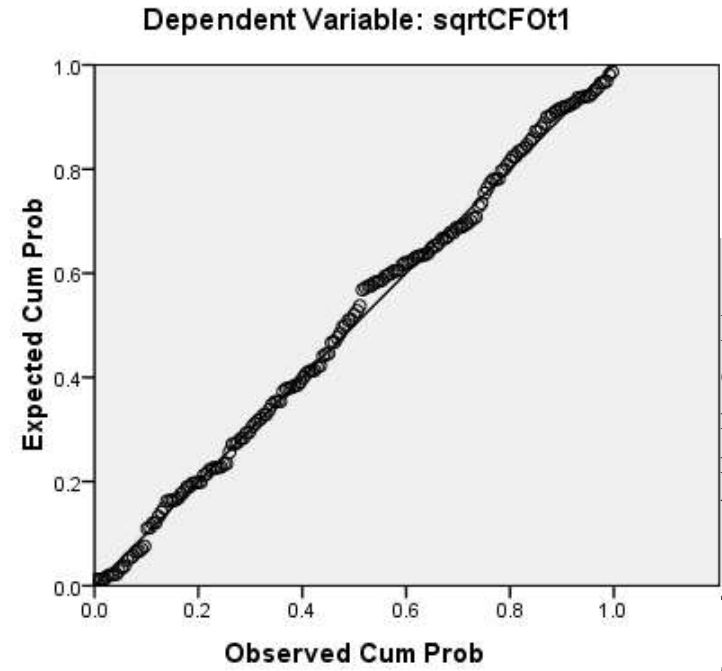

Hasil Pengujian Normalitas Arus Kas tahun $\mathrm{t}$ Normal P-P Plot of Regreasion standardized

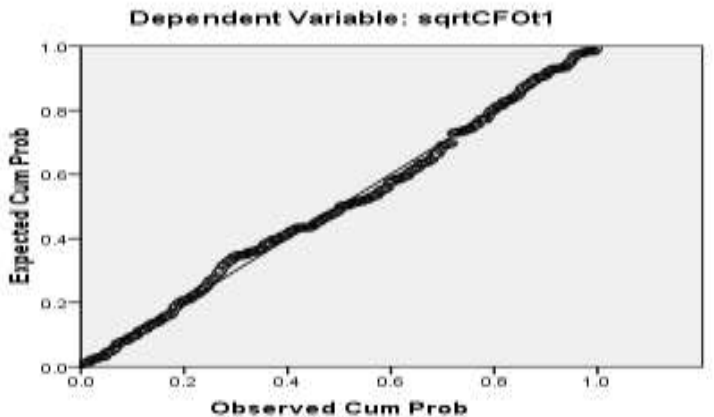

Gambar 4.3

Hasil Pengujian Normalitas Laba disagregat

Dari model 3 : $\mathrm{CFO}_{\mathrm{t}+1}=\boldsymbol{\alpha}_{0}+\boldsymbol{\alpha}_{1} \mathrm{CFO}_{\mathrm{t}}+$ $\alpha_{2} \mathbf{A C C}_{t}+\mu_{t}$ Normal P-P Plot of Regreasion standardized
Residual

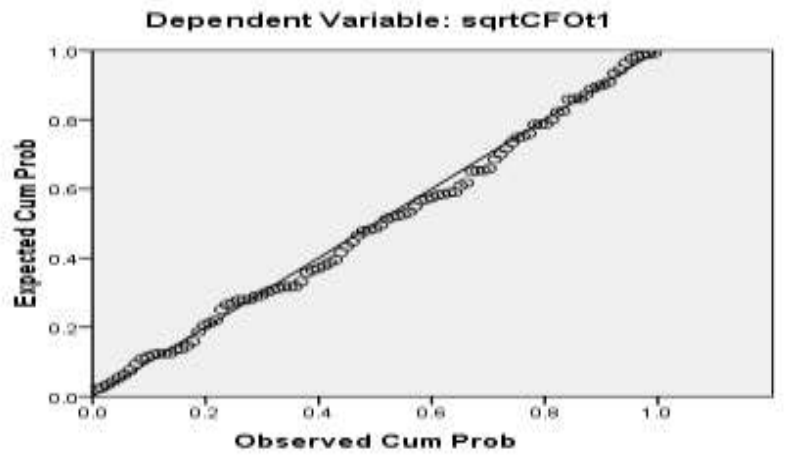

Dari Gambar 4.1, 4.2 dan 4.3 dapat dilihat bahwa hasil pengujian menunjukan bahwa distribusi data normal. Hal ini dapat dilihat dari terbentuknya satu garis diagonal.

\subsubsection{Multikolinearitas}

Tabel 4.2

Model $3:$ CFO $_{t+1}=\boldsymbol{\alpha}_{0}+\boldsymbol{\alpha}_{1} \mathbf{C F O}_{\mathbf{t}}+\boldsymbol{\alpha}_{2}$

$\mathrm{ACC}_{\mathrm{t}}+\mu_{\mathrm{t}}$

\section{Coefficients $^{\mathrm{a}}$}


Dari tabel diatas didapatkan bahwa nilai VIF dari laba disagregat adalah sebesar 1,205 dimana angka ini kurang dari 10 . Hal ini menunjukan bahwa tidak ada multikolinearitas. Model 1 dan 2 tidak diuji multikolinearitas karena persamaan berupa regresi linier sederhana.

\subsubsection{Heteroskedastisitas}

Uji ini menilai apakah ada ketidaksamaan varian dari residual untuk semua pengamatan pada model regresi linear. Uji yang digunakan adalah Glejser
Tabel 4.4

Colliheadty 1 : $\mathrm{CFO}_{\mathrm{t}+1}=\alpha_{0}+\alpha_{1} \mathrm{CFO}_{\mathrm{t}}+\mu_{\mathrm{t}}$

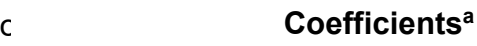

\begin{tabular}{|l|r|r|r|r|r|}
\hline \multirow{2}{*}{ Model } & \multicolumn{2}{|c|}{$\begin{array}{c}\text { Unstandardized } \\
\text { Coefficients }\end{array}$} & $\begin{array}{c}\text { Standar } \\
\text { dized } \\
\text { Coeffici } \\
\text { ents }\end{array}$ & \multirow{2}{*}{$\mathrm{t}$} & \multirow{2}{*}{ Sig. } \\
\cline { 2 - 5 } & \multicolumn{1}{|c|}{$\mathrm{B}$} & $\begin{array}{r}\text { Std. } \\
\text { Error }\end{array}$ & Beta & & \\
\hline 1 (Consta & $\begin{array}{r}\text { (5623. } \\
\text { nt) }\end{array}$ & $\begin{array}{r}6414.3 \\
55\end{array}$ & & 13.56 & .000 \\
CFOt & .007 & .006 & .080 & 1.206 & .229 \\
\hline
\end{tabular}

a. Dependent Variable: RES2

Kesimpulannya: Apabila nilai signifikansi (Sig.) $>0,05$ maka tidak terjadi gejala heteroskedastisitas. Dari output di atas, maka tampak bahwa variabel CFOt tidak ada gejala heteroskedastisitas karena Sig. $>0,05$.

Tabel 4.5

model $3: \mathbf{C F O}_{\mathbf{t + 1}}=\boldsymbol{\alpha}_{0}+\boldsymbol{\alpha}_{1} \mathbf{C F O}_{\mathbf{t}}+\boldsymbol{\alpha}_{2}$

$\mathrm{ACC}_{\mathrm{t}}+\mu_{\mathrm{t}}$

Tabel 4.3

Model 1: $\mathbf{C F O}_{\mathrm{t}+1}=\boldsymbol{\alpha}_{0}+\boldsymbol{\alpha}_{1} \mathbf{E A R N}_{\mathrm{t}}+\boldsymbol{\mu}_{\mathrm{t}}$

\begin{tabular}{|c|c|c|c|c|c|c|c|c|c|c|c|}
\hline \multirow{2}{*}{\multicolumn{5}{|c|}{$\begin{aligned} & \text { Model 1: } \mathbf{C F O}_{\mathrm{t}+1}= \boldsymbol{\alpha}_{0}+\boldsymbol{\alpha}_{1} \mathbf{E A R N}_{\mathrm{t}}+\boldsymbol{\mu}_{\mathrm{t}} \\
& \text { Coefficients }^{\mathrm{a}}\end{aligned}$}} & \multirow{2}{*}{\multicolumn{2}{|c|}{ Model }} & \multicolumn{2}{|c|}{ 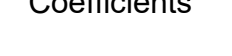 } & $\begin{array}{c}\text { CoentICI } \\
\text { ents }\end{array}$ & \multirow[t]{2}{*}{$\mathrm{t}$} & \multirow[t]{2}{*}{ Sig. } \\
\hline & & & & & & & B & $\begin{array}{l}\text { Std. } \\
\text { Error }\end{array}$ & Beta & & \\
\hline \multirow{3}{*}{ Model } & \multicolumn{2}{|c|}{$\begin{array}{l}\text { Unstandardiz } \\
\text { ed } \\
\text { Coefficients }\end{array}$} & \begin{tabular}{|c|} 
Standar \\
dized \\
Coeffici \\
ents \\
\end{tabular} & \multirow{3}{*}{$\mathrm{t}$} & \multirow{2}{*}{ S } & $\begin{array}{l}\text { (Const } \\
\text { ant) }\end{array}$ & $\begin{array}{r}93950 . \\
487 \\
\end{array}$ & $\begin{array}{r}17221 . \\
530\end{array}$ & $265 \mathrm{l}$ & 5.455 & .000 \\
\hline & & & & & & CFOt & -.020 & .031 & -.073 & -.670 & .505 \\
\hline & B & Error & Beta & & & & & & ES2 & & \\
\hline
\end{tabular}

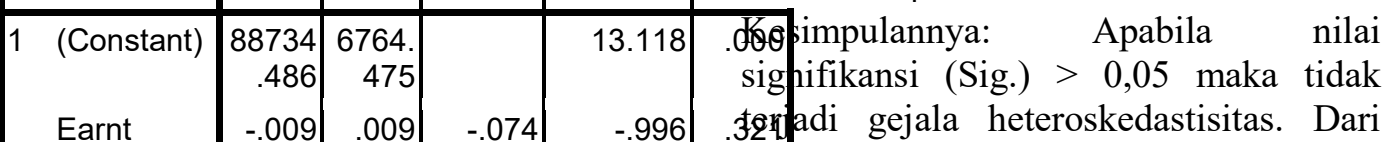

a. Dependent Variable: RES2

Jen adi gejala heteroskedastisitas. Dari output di atas, maka tampak bahwa variabel CFOt dan ACC tidak ada gejala

Kesimpulannya: Apabila nilai signifikansi (Sig.) > 0,05 maka tidak terjadi gejala heteroskedastisitas. Dari output di atas, maka tampak bahwa variabel EARNT tidak ada gejala heteroskedastisitas karena Sig. > 0,05.

\subsubsection{Autokorelasi}

Run test sebagai bagian dari statistik non - parametric dapat pula digunakan untuk menguji apakah antar residual terdapat korelasi yang tinggi. Jika antar residual 
tidak terdapat hubungan korelasi maka dikatakan bahwa residual adalah acak atau random

Tabel 4.6

Model 1: $\mathbf{C F O}_{\mathrm{t}+1}=\boldsymbol{\alpha}_{0}+\boldsymbol{\alpha}_{1} \mathbf{E A R N}_{\mathrm{t}}+\boldsymbol{\mu}_{\mathrm{t}}$

\begin{tabular}{|c|c|}
\hline \multicolumn{2}{|c|}{ Runs Test } \\
\hline & $\begin{array}{c}\text { Unstandardized } \\
\text { Residual }\end{array}$ \\
\hline Test Value ${ }^{a}$ & 5301.65747 \\
\hline Cases $<$ Test Value & 9 \\
\hline Cases $>=$ Test Value & 9 \\
\hline Total Cases & 18 \\
\hline Number of Runs & 16 \\
\hline $\mathrm{Z}$ & -2.446 \\
\hline Asymp. Sig. (2-tailed) & 16 \\
\hline
\end{tabular}

a. Median

Nilai signifikansi (Asymp.Sig (2-tailed)) $=0.164>\rho$ value 0.05 berarti tidak terjadi autokorelasi

Tabel 4.7

Model $2: \mathbf{C F O}_{\mathrm{t}+1}=\boldsymbol{\alpha}_{0}+\boldsymbol{\alpha}_{1} \mathbf{C F O}_{\mathrm{t}}+\boldsymbol{\mu}_{\mathrm{t}}$

\section{Runs Test}

\begin{tabular}{|l|r|}
\hline & $\begin{array}{c}\text { Unstandardized } \\
\text { Residual }\end{array}$ \\
\hline Test Value & a \\
Cases < Test Value & -3536.31658 \\
Cases >= Test Value & 115 \\
Total Cases & 115 \\
Number of Runs & 230 \\
Z & 132 \\
Asymp. Sig. (2-tailed) & 2.115 \\
\end{tabular}

a. Median

Nilai signifikansi (Asymp.Sig (2-tailed)) $=0.074>\rho$ value 0.05 berarti tidak terjadi autokorelasi

Tabel 4.8

model 3: $\mathbf{C F O}_{\mathrm{t}+1}=\boldsymbol{\alpha}_{0}+\boldsymbol{\alpha}_{1} \mathbf{C F O}_{\mathbf{t}}+\boldsymbol{\alpha}_{2}$

$\mathrm{ACC}_{\mathrm{t}}+\mu_{\mathrm{t}}$

\begin{tabular}{|l|r|}
\hline \multicolumn{2}{|c}{ Runs Test } \\
\hline \multicolumn{1}{|c|}{$\begin{array}{c}\text { Unstandardized } \\
\text { Residual }\end{array}$} \\
\hline Test Value & -5221.92521 \\
Cases < Test Value & 49 \\
Cases >= Test Value & 50 \\
Total Cases & 99 \\
Number of Runs & 52 \\
Z & .304 \\
Asymp. Sig. (2-tailed) & .761 \\
\hline
\end{tabular}

\section{a. Median}

Nilai signifikansi (Asymp.Sig (2-tailed)) $=0.761>\rho$ value 0.05 berarti tidak terjadi autokorelasi

\subsection{Analisis Regresi Berganda}

\subsubsection{Uji $F$}

Tabel 4.9

Model 1: $\mathbf{C F O}_{\mathrm{t}+1}=\boldsymbol{\alpha}_{0}+\boldsymbol{\alpha}_{1} \mathbf{E A R N}_{\mathrm{t}}$ $+\mu_{\mathrm{t}}$

ANOVA $^{b}$

\begin{tabular}{|l|r|r|r|r|r|}
\hline Model & $\begin{array}{c}\text { Sum of } \\
\text { Squares }\end{array}$ & df & $\begin{array}{r}\text { Mean } \\
\text { Squar } \\
\text { e }\end{array}$ & $F$ & Sig. \\
\hline $\begin{array}{l}\text { 1 Regres } \\
\text { sion }\end{array}$ & $4.810 \mathrm{E} 13$ & 1 & $\begin{array}{r}4.810 \\
\mathrm{E} 13\end{array}$ & $\begin{array}{r}4486 \\
390\end{array}$ & $.000^{\mathrm{a}}$ \\
$\begin{array}{l}\text { Residu } \\
\text { al }\end{array}$ & $1.940 \mathrm{E} 12$ & 181 & $\begin{array}{r}1.072 \\
\mathrm{E} 10\end{array}$ & & \\
Total & $5.004 \mathrm{E} 13$ & 182 & & & \\
\hline
\end{tabular}

a. Predictors: (Constant), sqrtEarnt

b. Dependent Variable: sqrtCFOt1

Dari tabel di atas dapat dilihat bahwa nilai $p$-value dari model penelitian laba agregat sebesar 0,000 . Karena p-value jauh lebih kecil dari tingkat signifikansi yaitu 0,05, maka dapat disimpulkan bahwa model regresi dapat digunakan untuk meprediksi arus kas operasi dimasa mendatang $\left(\mathrm{CFO}_{\mathrm{t}+1}\right)$ atau dapat dikatakan EARN $_{t}$ berpengaruh terhadap arus kas operasi di masa mendatang. 
Tabel 4.10

Model $2: \mathbf{C F O}_{t+1}=\boldsymbol{\alpha}_{0}+\boldsymbol{\alpha}_{1} \mathbf{C F O}_{t}+$ $\boldsymbol{\mu}_{\mathrm{t}}$

ANOVA $^{b}$

\begin{tabular}{|c|c|c|c|c|c|}
\hline Model & $\begin{array}{l}\text { Sum of } \\
\text { Squares }\end{array}$ & df & $\begin{array}{l}\text { Mean } \\
\text { Square }\end{array}$ & $\mathrm{F}$ & $\begin{array}{l}\text { Tab l } 4.12 \\
\text { siqgodel 1: CFO } \\
t+1=\alpha_{0}+\alpha_{1} \text { EARN }_{t}\end{array}$ \\
\hline Rearessi & 1.420E14 & & 8 & 64 & $.990^{a}$ \\
\hline
\end{tabular}

on

Residual $3.040 \mathrm{E} 12$ 228 $1.333 \mathrm{E} 10$

Total

1.450E14

a. Predictors: (Constant), sqrtCFOt

b. Dependent Variable: sqrtCFOt1

Dari tabel di atas dapat dilihat bahwa nilai p-value dari model penelitian arus kas sebesar 0,000. Karena p-value jauh lebih kecil dari tingkat signifikansi yaitu 0,05 , maka dapat disimpulkan bahwa model regresi dapat digunakan untuk meprediksi arus kas operasi dimasa mendatang $\left(\mathrm{CFO}_{\mathrm{t}+1}\right)$ atau dapat dikatakan arus kas tahun berjalan berpengaruh terhadap arus kas operasi di masa mendatang.

Tabel 4.11

Model 3: $\mathbf{C F O}_{t+1}=\boldsymbol{\alpha}_{0}+\boldsymbol{\alpha}_{1} \mathbf{C F O}_{t}+$ $\alpha_{2} \mathrm{ACC}_{\mathrm{t}}+\mu_{\mathrm{t}}$

\begin{tabular}{|c|c|c|c|c|c|}
\hline \multicolumn{6}{|c|}{ ANOVA $^{b}$} \\
\hline Model & $\begin{array}{l}\text { Sum of } \\
\text { Squares }\end{array}$ & df & $\begin{array}{l}\text { Mean } \\
\text { Square }\end{array}$ & $F$ & Sig. \\
\hline $\begin{array}{ll}1 & \begin{array}{l}\text { Regres } \\
\text { sion }\end{array}\end{array}$ & $8.215 \mathrm{E} 12$ & 2 & 4.107E12 & $\begin{array}{r}233.2 \\
31\end{array}$ & .000 \\
\hline $\begin{array}{l}\text { Residu } \\
\text { al }\end{array}$ & 1.603E12 & 91 & $1.761 \mathrm{E} 10$ & & \\
\hline Total & $9.818 \mathrm{E} 12$ & 93 & & & \\
\hline
\end{tabular}

a. Predictors: (Constant), sqrtCFOt, sqrtACC

b. Dependent Variable: sqrtCFOt1

Dari tabel di atas dapat dilihat bahwa nilai $p$-value dari model penelitian sebesar 0,000 . Karena $\mathrm{p}$ value jauh lebih kecil dari tingkat signifikansi yaitu 0,05 , maka dapat disimpulkan bahwa model regresi dapat digunakan untuk meprediksi arus kas operasi dimasa mendatang $\left(\mathrm{CFO}_{\mathrm{t}+1}\right)$ atau dapat dikatakan laba yang di disagregatkan mejadi komponen akrual dan arus kas tahun berjalan berpengaruh terhadap arus kas operasi di masa mendatang.

\subsubsection{Uji t}

\begin{tabular}{|c|c|c|c|c|c|}
\hline \multirow[b]{2}{*}{ Model } & \multicolumn{2}{|c|}{$\begin{array}{l}\text { Unstandardized } \\
\text { Coefficients }\end{array}$} & \multirow{2}{*}{\begin{tabular}{|c}
$\begin{array}{c}\text { Standar } \\
\text { dized } \\
\text { Coeffici } \\
\text { ents }\end{array}$ \\
Beta
\end{tabular}} & \multirow[b]{2}{*}{$t$} & \multirow[b]{2}{*}{ Sig. } \\
\hline & B & $\begin{array}{l}\text { Std. } \\
\text { Error }\end{array}$ & & & \\
\hline 1 (Constant) & $\begin{array}{r}14767.89 \\
7\end{array}$ & $\begin{array}{r}11633 . \\
607\end{array}$ & & 1.269 & .206 \\
\hline Earnt & 1.037 & .015 & .980 & 66.981 & .000 \\
\hline
\end{tabular}

a. Dependent Variable: sqrtCFOt1

Pada Tabel 4.12 dapat dilihat bahwa tingkat signifikansi yang dihasilkan laba bersih atau laba agregat adalah sebesar 0,000. Dengan demikian, nilai p-value $(0,000)<\alpha(0,05)$, yang berarti H0 ditolak. Maka dapat disimpukan bahwa laba bersih memiliki kemampuan dalam memprediksi arus kas masa depan.

Tabel 4.13

Model 2: $\mathbf{C F O}_{\mathrm{t}+1}=\boldsymbol{\alpha}_{0}+\boldsymbol{\alpha}_{1} \mathbf{C F O}_{\mathrm{t}}+$ $\mu_{t}$

\section{Coefficients $^{\mathrm{a}}$}

\begin{tabular}{|c|c|c|c|c|c|}
\hline \multirow[b]{2}{*}{ Model } & \multicolumn{2}{|c|}{$\begin{array}{l}\text { Unstandardized } \\
\text { Coefficients }\end{array}$} & \multirow{2}{*}{\begin{tabular}{|c}
$\begin{array}{c}\text { Standar } \\
\text { dized } \\
\text { Coeffici } \\
\text { ents }\end{array}$ \\
Beta
\end{tabular}} & \multirow[b]{2}{*}{$\mathrm{t}$} & \multirow[b]{2}{*}{ Sig. } \\
\hline & B & $\begin{array}{l}\text { Std. } \\
\text { Error }\end{array}$ & & & \\
\hline $\begin{array}{l}1 \text { (Consta } \\
\mathrm{nt})\end{array}$ & $\begin{array}{r}15875 . \\
678\end{array}$ & $\begin{array}{r}10320 . \\
999\end{array}$ & & 1.538 & .12 \\
\hline CFOt & 1.011 & .010 & .989 & $\begin{array}{r}103.1 \\
90\end{array}$ & .00 \\
\hline
\end{tabular}

a. Dependent Variable: sqrtCFOt1

Pada Tabel 4.13 dapat dilihat bahwa tingkat signifikansi yang dihasilkan arus kas masa tahun berjalan adalah sebesar 0,000. Dengan demikian, nilai p-value $(0,000)<\alpha(0,05)$, 
yang berarti $\mathrm{H} 0$ ditolak. Maka dapat disimpukan bahwa arus kas tahun berjalan memiliki kemampuan dalam memprediksi arus kas masa depan

Tabel 4.14

Model 3: $\mathbf{C F O}_{\mathrm{t}+1}=\boldsymbol{\alpha}_{0}+\boldsymbol{\alpha}_{\mathbf{1}} \mathbf{C F O}_{\mathrm{t}}+$ $\alpha_{2} \mathrm{ACC}_{\mathrm{t}}+\mu_{\mathrm{t}}$

\begin{tabular}{|l|r|r|r|r|r|}
\hline \multicolumn{1}{|c|}{ Coefficients $^{\mathrm{a}}$} \\
& $\begin{array}{c}\text { Unstandardiz } \\
\text { ed } \\
\text { Coefficients }\end{array}$ & $\begin{array}{c}\text { Standar } \\
\text { dized } \\
\text { Coeffici } \\
\text { ents }\end{array}$ & & \\
\cline { 2 - 4 } Model & \multicolumn{1}{|c|}{$\mathrm{B}$} & Std. & & \\
\hline 1 Error & Beta & $\mathrm{t}$ & Sig. \\
(Con & 55815 & 26379 & & 2.116 & .037 \\
stant & .502 & .295 & & & \\
ACC & .176 & .061 & .134 & 2.897 & .005 \\
CFOt & .842 & .046 & .853 & 18.425 & .000 \\
\hline
\end{tabular}

a. Dependent Variable: sqrtCFOt1

Pada Tabel 4.14 dapat dilihat bahwa tingkat signifikansi yang dihasilkan laba agregat (akrual dan arus kas mas kini) adalah sebesar 0,000 dan 0.005 . Dengan demikian, nilai $\mathrm{p}$ value $(0,000)<\alpha(0,05)$, yang berarti $\mathrm{H} 0$ ditolak. Maka dapat disimpukan bahwa laba yang di disagregatkan dalam bentuk akrual dan arus kas tahun berjalan memiliki kemampuan dalam memprediksi arus kas masa depan

\subsubsection{Koefisien Determinasi $\left(R^{2}\right)$}

Nilai yang diperoleh dari koefisien determinasi digunakan untuk mengukur seberapa jelas kemampuan variabel independen secara bersamaan dalam menjelaskan variabel dependen.

Tabel 4.15

Model 1: $\mathbf{C F O}_{\mathrm{t}+1}=\boldsymbol{\alpha}_{0}+\boldsymbol{\alpha}_{1} \mathbf{E A R N}_{\mathrm{t}}$

$+\mu_{\mathrm{t}}$

\begin{tabular}{|c|c|c|c|c|c|}
\hline \multicolumn{6}{|c|}{ Model Summaryb } \\
\hline $\begin{array}{l}\text { Mod } \\
\text { el }\end{array}$ & $\mathrm{R}$ & $\begin{array}{c}\mathrm{R} \\
\text { Square }\end{array}$ & \begin{tabular}{|c} 
Adjust \\
ed R \\
Squar \\
e
\end{tabular} & $\begin{array}{l}\text { Std. Error } \\
\text { of the } \\
\text { Estimate }\end{array}$ & $\begin{array}{c}\text { Durbi } \\
n- \\
\text { Wats } \\
\text { on }\end{array}$ \\
\hline 1 & $.995^{a}$ & .981 & .980 & $\begin{array}{r}1.03542 \mathrm{E} \\
5\end{array}$ & 1.736 \\
\hline
\end{tabular}

a. Predictors: (Constant), Earnt

b. Dependent Variable: CFOt1

Dari tabel 4.15 dapat dilihat bahwa angka $\mathbf{R}^{2}$ dalam model penelitian laba agregat sebesar 0,981 atau $98,1 \%$. Hal ini menunjukan bahwa laba agregat atau laba bersih dapat menjelaskan $98,1 \%$ variasi arus kas masa depan. Sedangkan sisanya $(100 \%-98,1 \%)=1,9 \%$ dijelaskan oleh sebab-sebab yang lain diluar model.

Tabel 4.16

Model 2: $\mathbf{C F O}_{\mathrm{t}+1}=\boldsymbol{\alpha}_{0}+\boldsymbol{\alpha}_{1} \mathbf{C F O}_{\mathbf{t}}+$ $\mu_{\mathrm{t}}$

Model Summary ${ }^{b}$

\begin{tabular}{|l|c|r|r|r|c|}
\hline $\begin{array}{l}M \\
\text { od } \\
\text { el }\end{array}$ & $R$ & $\begin{array}{c}\mathrm{R} \\
\text { Square }\end{array}$ & $\begin{array}{c}\text { Adjust } \\
\text { ed R } \\
\text { Squar } \\
\mathrm{e}\end{array}$ & $\begin{array}{c}\text { Std. Error } \\
\text { of the } \\
\text { Estimate }\end{array}$ & $\begin{array}{c}\text { Durbi } \\
\mathrm{n}- \\
\text { Wats } \\
\text { on }\end{array}$ \\
\hline 1 & $.989^{\mathrm{a}}$ & .979 & .979 & $\begin{array}{r}1.15467 \mathrm{E} \\
5\end{array}$ & 2.221 \\
\hline
\end{tabular}

a. Predictors: (Constant), sqrtCFOt

b. Dependent Variable: sqrtCFOt1

Dari tabel 4.16 dapat dilihat bahwa angka $\mathbf{R}^{2}$ dalam model penelitian laba agregat sebesar 0,979 atau 97,9\%. Hal ini menunjukan bahwa arus kas tahun berjalan dapat menjelaskan 97,9\% variasi arus kas masa depan. Sedangkan sisanya $(100 \%-97,9 \%)=2.1 \%$ dijelaskan oleh sebab-sebab yang lain diluar model.

Tabel 4.17

Model $3: \mathbf{C F O}_{t+1}=\boldsymbol{\alpha}_{0}+\boldsymbol{\alpha}_{\mathbf{1}} \mathbf{C F O}_{\mathbf{t}}+$ $\alpha_{2} \mathrm{ACC}_{\mathrm{t}}+\mu_{\mathrm{t}}$ 


\begin{tabular}{|l|r|r|r|r|r|}
\hline \multicolumn{7}{|c|}{ Model Summary } \\
\hline $\begin{array}{c}M \\
\text { od } \\
\mathrm{el}\end{array}$ & $\mathrm{R}$ & $\begin{array}{c}\mathrm{R} \\
\text { Square }\end{array}$ & $\begin{array}{c}\text { Adjust } \\
\text { ed R } \\
\text { Squar } \\
\mathrm{e}\end{array}$ & $\begin{array}{c}\text { Std. Error } \\
\text { of the } \\
\text { Estimate }\end{array}$ & $\begin{array}{r}\text { Durbin- } \\
\text { Watson }\end{array}$ \\
\hline 1 & $.996^{\mathrm{a}}$ & .986 & .984 & $1.32707 \mathrm{E}$ & 2.351 \\
\hline
\end{tabular}

a. Predictors: (Constant), CFOt, ACC

b. Dependent Variable: CFOt1

Dari tabel 4.17 dapat dilihat bahwa angka $\mathbf{R}^{2}$ dalam model penelitian laba disagregat sebesar 0,986 atau $98,6 \%$. Hal ini menunjukan bahwa laba yang didisagregatkan menjadi komponen akrual dan arus kas tahun berjalan dapat menjelaskan $98,6 \%$ variasi arus kas masa depan. Sedangkan sisanya $(100 \%-98,6 \%)=$ $1,4 \%$ dijelaskan oleh sebab-sebab yang lain diluar model.

\subsection{Pembahasan}

Berdasarkan penelitian yang telah dilakukan, maka dilanjutkan dengan pembahasan sesuai dengan hipotesis yang telah ditentukan pada bagian sebelumnya, pembahasan atas penelitian adalah sebagai berikut :

\subsubsection{Laba Bersih Mengungguli Arus Kas dalam Memprediksi Arus Kas Masa Depan}

Hasil penelitian di atas menunjukkan bahwa laba bersih atau laba agregat dapat mengungguli arus kas dalam memprediksi arus kas masa depan. Hal tersebut dapat dilihat dari analisis koefisien determinasi. Laba bersih atau laba agregat memiliki angka $\mathbf{R}^{2}$ sebesar $98,1 \%$, lebih besar dari angka $\mathbf{R}^{\mathbf{2}}$ yang dimiliki arus kas tahun berjalan yaitu, $97,9 \%$. Hasil dari analisis tersebut juga menyimpulkan bahwa laba agregat memiliki kemampuan yang lebih besar dalam memprediksi arus kas masa depan dibandingkan dengan laba agregat.

Hal ini sesuai dengan penelitian yang dilakukan oleh Ibrahim el-sayed (2011). Menurut Ibrahim el-sayed (2011) dalam penelitiannya mengenai kemampuan laba, arus kas, perubahan piutang, perubahan persediaan, perubahan utang, eban depresiasi dan komponen akrual lainnya dalam memprediksi arus kas 1. hasa depan, menyatakan bahwa laba themiliki pengaruh yang lebih dalam memprediksi arus kas masa depan, dibandingkan dengan arus kas tahun berjalan.

\subsubsection{Komponen Laba Disagregat Mengungguli Kemampuan Laba dalam Memprediksi Arus Kas Masa Depan \\ Hasil penelitian di atas menunjukkan} bahwa komponen-komponen yang terkandung dalam laba disagregat, yaitu komponen akrual dan arus kas tahun berjalan dapat meningkatkan kemampuan laba dalam memprediksi arus kas. Dalam analisis koefisien determinasi dapat dilihat bahwa angka $\mathbf{R}^{2}$ yang dimiliki laba disagregat yaitu sebesar 98,6\%, lebih besar dari angka $\mathbf{R}^{\mathbf{2}}$ yang dimiliki laba agregat yaitu 98,1\%. Hal tersebut menunjukan bahwa komponen laba disagregat meningkatkan kemapuan dalam memprediksi arus kas masa depan. Hal ini juga sesuai dengan penelitian yang dilakukan oleh Ebaid (2011). Dalam penelitiannya Ebaid (2011) meyimpulkan bahwa laba yang didisagregatkan menjadi komponen akrual dan arus kas tahun berjalan memiliki meningkatkan kemampuan prediksi laba dalam memprediksi arus kas masa depan. Dimana komponen akrual menjadi komponen utama yang meningkatkan kemampuan predisi laba.

\section{KESIMPULAN}

Penelitian ini dilakukan untuk mengetahui kemampuan laba bersih yang mengungguli arus kas tahun berjalan dalam memprediksi arus kas masa depan dan untuk mengetahui komponen laba disgaregat dalam meningkatkan kemampuan laba untuk memprediksi arus kas masa depan. 
Populasi dari penelitian ini adalah perusahaan yang bergerak di bidang manufaktur dan jasa non keuangan yang terdaftar di BEI dari tahun 2012 sampai dengan 2016. Pengambilan sampel dilakukan dengan menggunakan metode purposive sampling method. Penelitian tersebut menggunakan tiga model penelitian. Pengujian hipotesis dilakukan dengan menggunakan analisis regresi berganda dengan tingkat signifikan 5\%. Kesimpulan yang diperoleh adalah bahwa laba mengungguli arus kas tahun berjalan dalam memprediksi arus kas masa depan. Hasil ini sesuai dengan penelitian Ibrahim el-sayed (2011), yang menyatakan bahwa laba bersih memiliki kemampuan yang lebih dalam memeprediksi arus kas dibandingkan dengan kemampuan arus kas tahun berjalan. Hasil selanjutnya yang terkait dengan hipotesis kedua adalah bahwa komponen laba disagregat mengungguli kemampuan laba dalam memprediksi arus kas masa depan. Hal ini sesuai dengan penelitian yang dilakukan Ebaid (2011 yang menyatakan bahwa komponen yang terkandung dalam laba disagregat yaitu arus kas tahun berjalan dan komponen akrual dapat meningkatkan kemampuan dalam hal memprediksi arus kas masa depan.

\section{DAFTAR PUSTAKA}

Aghei M.A. Shakeri, Amir. "Application Cash Flow Ratios, Cash Flows And Accrual Accounting In Predicting Future Operating Cash Flow In Listed Companies Of Tehran Stock Exchange". Financial Accounting, Spring 2010, Vol. 2, No.5, pp. 1-16

Ebaid, I.E.S. (2011), "Accruals and the prediction of future cash fows: empirical evidence from an emerging market", Management Research Review, Vol. 34 No. 7, pp. $838-853$
Dawar, Varun. (2014), "The relative predictive ability of earnings and cash fows Relative predictive ability of earnings Evidence from Shariah compliant companies in India", Management Research Review,Vol. 38 No. 4, 2015, pp. 367-380.

Dechow, P.M. (1994), “Accounting earnings and cash fows as measures of frm performance: the role of accounting accruals", Journal of Accounting and Economics, Vol. 18 No. 1, pp. 3 42

Ikatan Akuntan Indonesia. (2014). Standar Akuntansi Keuangan: per 1 Januari 2015. Jakarta: Ikatan Akuntan Indonesia.

Kieso, E. Donald. Weygandt Jerry J, Warfield Terry D.Intermediate Accounting: Principles and Analysis. Second Edition. Hoboken,NJ: John Wiley \&Sons, Inc., 2008, pp. xxx, 1079.

Munawir.(2010). Analisis Laporan Keuangan, Edisi Keempat. Liberty. Yogyakarta.

Sloan, R.G. (1996), "Do stock prices fully refect information in accruals and cash fows about future earnings", The Accounting Review, Vol. 71 No. 3, pp. 289315.

Stice and Skousen (2007). Intermediate Accounting $13^{\text {th }}$ edition.

Takhtaei, Nasrollah. Karimi, Hasan (2013). "Relative Ability of Earnings Data and Cash Flow in Predicting Future Cash Flows". International Journal of Accounting and Financial Reporting ISSN 2162-3082 2013, Vol. 3, No. 1, pp. 214-226. 
Zhen, Claudia. Zhang, Jieying. Subramanyam "Accrual quality, bond liquidity, and cost of debt" Working paper, 2010. msbfile03.usc.edu 